\title{
Provincial Governance in Iraq: Councils, Contestation, and Capacity Building
}

Lamar Cravens and Derick W. Brinkerhoff

August 2013 


\section{About the Authors}

Lamar Cravens, JD, LLM, MA, is Chief of Party, Deloitte Consulting, on the U.S. Agency for International Development's Local Governance Project in Tajikistan. An attorney specializing in Muslim countries in transition, Mr. Cravens worked on all three phases of the Iraq Local Governance Program (LGP), from August 2003 through September 2011. His resident positions included Legal Advisor, Provincial Team Leader, Regional Team Leader, Deputy Chief of Party, and finally Chief of Party for LGP III.

Derick W. Brinkerhoff, EdD, MAdmin, is Distinguished Fellow in International Public Management, RTI International. Dr. Brinkerhoff was a decentralization policy advisor to LGP, with shortterm visits to Iraq in 2003, 2004, and 2010. His research interests include governance in post-conflict transitions, decentralization, citizen participation, and policy implementation.
This publication is part of the RTI Research Report series. Occasional Papers are scholarly essays on policy, methods, or other topics relevant to RTI areas of research or technical focus.

RTI International

3040 Cornwallis Road

PO Box 12194

Research Triangle Park, NC

27709-2194 USA

Tel: $\quad+1.919 .541 .6000$

Fax: $\quad+1.919 .541 .5985$

E-mail:_rtipress@rti.org

Web site: www.rtiorg
RTI Press publication OP-0015-1308

This PDF document was made available from www.rti.org as a public service of RTI International. More information about RTI Press can be found at http://www.rti.org/rtipress.

RTI International is an independent, nonprofit research organization dedicated to improving the human condition by turning knowledge into practice. The RTI Press mission is to disseminate information about RTI research, analytic tools, and technical expertise to a national and international audience. RTI Press publications are peer-reviewed by at least two independent substantive experts and one or more Press editors.

\section{Suggested Citation}

Cravens, L., \& Brinkerhoff, D. W. (2013). Provincial governance in Iraq:

Councils, contestation, and capacity building (RTI Press publication

OP-0015-1308). Research Triangle Park, NC: RTI Press.
C2013 Research Triangle Institute. RTI International is a trade name of Research Triangle Institute.

All rights reserved. This report is protected by copyright. Credit must be provided to the author and source of the document when the content is quoted. Neither the document nor partial or entire reproductions may be sold without prior written permission from the publisher. www.rti.org/rtipress 


\section{Provincial Governance in Iraq: Councils, Contestation, and Capacity Building}

\author{
Lamar Cravens and Derick W. Brinkerhoff
}

\begin{abstract}
Assessments of the United States-led effort to create a democratically governed Iraq following the toppling of the Saddam Hussein regime in 2003 have generally been negative. However, these criticisms have, for the most part, ignored the progress Iraq made on putting in place basic public administration practices and political processes that better serve its citizens, particularly at the subnational level. This paper reviews the experience of the Local Governance Program in strengthening the capacities of subnational councils and provincial offices to develop legislation and to plan and budget for capital investments. The discussion reveals how contestation over the legal interpretations of decentralization constrained the autonomy of provincial actors, and how mastery of administrative tools and methods enabled them to maneuver more effectively within evolving provincial governance structures. This experience offers several lessons for international stabilization and reconstruction operations: constitution-making in divided societies paves over differences with ambiguities in order to reach agreement, which pushes the unresolved conflicts into political, legislative, and administrative arenas; decentralization debates are ultimately about the distribution of political power and control and cannot be addressed solely as technical and administrative governance questions; and basic public administration capacity is critical to meeting citizens' expectations for services, security, and economic opportunity. A final observation is that international governance improvement templates can only be effective if they recognize that technical interventions must account for politics and the incentives facing local actors.
\end{abstract}

This paper draws upon the authors' direct experience with the Iraq Local Governance Program (LGP). The views expressed regarding Iraq, LGP, and the reconstruction effort are solely those of the authors and should not be attributed to USAID or RTI International.

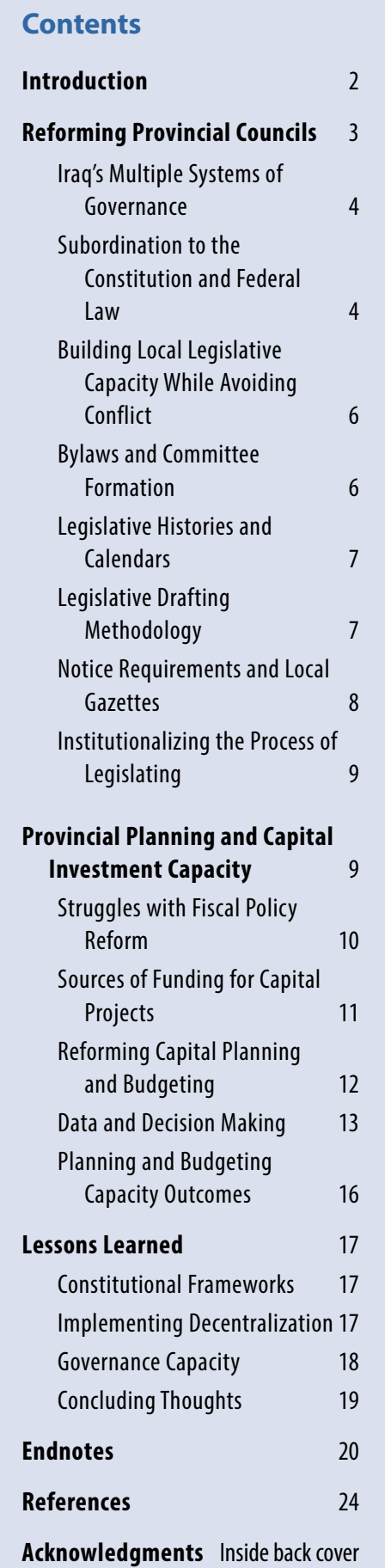




\section{Introduction}

The passage in the spring of 2013 of the 10 -year anniversary of the United States-led invasion of Iraq and the launch of the ambitious reconstruction program has occasioned an outpouring of reflection, assessment, and critical review by government officials, military leaders, politicians, pundits, analysts, academicians, and members of the international development community. Persistent violence, sectarian and regional conflict, high levels of corruption, and Prime Minister Nuri al-Maliki's increasingly authoritarian consolidation of centralized power-to name a few commonly cited current issues-are taken as signs of the failure of the reconstruction effort to achieve the objectives of a stable, peaceful, prosperous, and democratic Iraq.

The reports of the Special Inspector General for Iraq Reconstruction have painted a sobering picture of unrealistic and uncoordinated planning and execution, bureaucratic inefficiency, ineffective oversight, waste, and corruption (Special Inspector General for Iraq Reconstruction [SIGIR], 2009, 2013). Democracy specialists have pointed out the folly of ideologically driven templates to graft federalist democracy and free-market liberalism onto Iraq (e.g., Amato, 2009; Diamond, 2005). Middle East and Iraq scholars have documented the ways in which reconstruction outsiders ignored and/or misperceived history and current realities on the ground and inadvertently contributed to vicious cycles and pernicious outcomes (see Dodge 2003, 2012; Brown, 2005; Feldman, 2004; Visser, 2010).

Many of these criticisms raise valid issues, and the experience in Iraq should be dissected to identify lessons for future stabilization and reconstruction operations. Despite some echoes of the "never again" conclusion drawn post-Vietnam, policymakers recognize that in today's world, the need for such operations will not disappear. Yet largely lost in the spate of contemporary policy reviews of the nationbuilding effort in Iraq is attention to what small steps toward better governance were taken. While "big D" democracy was imperfectly implanted in Iraq, some progress on the mechanics of governance and basic public administration was achieved. ${ }^{1}$
Without some minimum competency in public administration, states are unable to fulfill what Whaites (2008) terms either "survival" functions (ability to maintain security, raise revenue, and govern through the rule of law) or "expected" functions (ability to meet citizens' expectations for services, infrastructure, etc.). In conflict-affected states, improving performance of these functions is critical to building public confidence, creating legitimacy, and establishing peaceful, constructive, and stable state-society relations (Organisation for Economic Co-operation and Development/ Development Assistance Committee, 2008; United Nations, 2010). Basic administrative capacity is important not just for central government, but for subnational entities as well (see Brinkerhoff, 2011).

This paper offers an account of two sets of activities of the Local Governance Program (LGP), funded by the U.S. Agency for International Development (USAID), that aimed to strengthen the capacities of subnational councils and provincial offices: the development of local legislation, and local planning and budgeting for provincial investment. ${ }^{2}$ We chose these activities in order to focus on the nitty-gritty basics of public policy and administration, a viewpoint that is often missing in broad discussions about democracy and governance. Our narrative sheds light on Iraq's checkered path from a highly centralized governance system to a more decentralized one. ${ }^{3}$ Three main themes are woven throughout the narrative and analysis:

- The contestation over decentralization played out through conflicting interpretations of the new legal architecture of the Iraqi state, which influenced the distribution of authority and responsibility. Progress with decentralization depended upon an in-depth understanding of the new architecture and the ability to use that understanding to create and protect space for some degree of autonomous provincial governance. 
- As new governance actors, provincial councils and governors' offices needed to acquire basic capacities in legislating, planning, budgeting, managing, and interacting with constituents and citizens. These capacities proved critical to their ability to fulfill their legally mandated functions, to build competence and legitimacy in the eyes of both central government and local citizens, and to proactively navigate the governance landscape that Iraq's new legal architecture put in place.

- While the evolving accommodation between central and local governance actors took place through debates and deliberations framed around constitutional, legal, and administrative interpretations of authority and responsibility, the fundamental dynamic at play was-and continues to be-competition for political power. The ouster of the Saddam Hussein regime created space for new actors to renegotiate the Iraqi state's political and ethno-religious pact, an ongoing process that has been punctuated with eruptions of fractiousness, sectarianism, and occasional violence.

The paper looks first at elected provincial councils, beginning with an overview of Iraq's governance systems and the constitutional and legal framework within which councils operated. The next sections detail the legislative strengthening activities carried out by LGP that led to better quality local legislation and increases in councils' capacity to fulfill their roles and responsibilities. The paper then turns to provincial planning, budgeting, and capital investment. After reviewing the fiscal constraints facing the councils and the sources of funding for capital investments, the discussion turns to how LGP worked with the councils and governors' offices to reform the planning and budgeting process. We present capacity building efforts for data collection and decision-making that support the plans and budgets, and we report budget execution results. The paper concludes with lessons learned related to constitutions, decentralization, and capacity building strategies.

\section{Reforming Provincial Councils}

The Coalition Provisional Authority (CPA), Iraq's occupation government, suspended the Iraqi Constitution of 1970 and initiated steps that were aimed at diffusing authority and power so as to reduce the risk of future dictatorial rule and to create a state that would respond to the needs and desires of its citizens. ${ }^{4}$ CPA Order 71 and the Transitional Administrative Law (TAL, the interim constitution), were the first steps in that direction and included provisions for subnational governments. These documents were replaced by the Iraqi Constitution of 2005, ratified by popular referendum (see Amato, 2009; Brown, 2005). The constitution and the subsequent 2008 Law of Governorates Not Incorporated into a Region created the architecture for democratic and decentralized governance. Ambiguities in the documents, differing interpretations of authorities, central-provincial tensions, and capacity gaps made the road to implementation of the new governance system a rocky one. Iraq's modern history of strong centralized control also posed an impediment to change. Some provincial actors sought to take advantage of the newly created discretionary space, but others hesitated, awaiting guidance from Baghdad.

An early target of governance reform was the provincial (governorate) councils. These existed before the American-led invasion, but they were largely instruments of central control. Their members were not elected and usually consisted of the directors general of provincial-level offices of central government ministries and other Ba'ath Party officials. Their primary role was to serve an advisory function for the provincial governor, who was himself appointed by Baghdad and accountable in the first instance to the Ministry of Interior.

The CPA dissolved and reconstituted existing councils, employing a variety of methods to select members (see Brinkerhoff \& Tadesse, 2005). National elections to the provincial councils were first held in January 2005, before Iraqis adopted their new constitution later that year. In January 2009, a new slate of provincial council candidates was elected in a more open process and under the auspices of the new governorates law. 
Due to the compromises necessary to secure ratification of both the Constitution of 2005 and the Law of Governorates of 2008 (Law 21), demarcation between the authorities of the central government and what the constitution refers to as "other administrative units" was unclear. Articles in both documents suggest simultaneously a strong central government and independent provincial governance. In the years since their adoption, custom evolved to clarify the law, as central government and provincial officials accommodated their occasionally competing interests to give meaning to the sometimes vague, sometimes silent articles. This accommodation was evident in the evolution of provincial councils' pursuit of authority to issue local legislation.

The Law of Governorates describes a provincial council as the "highest legislative authority" in the territory of its province but limits the scope of that authority to subjects not already covered by federal law. The Local Governance Program, Phase III (LGP III) helped the councils to exercise their legislative responsibilities within the new legal architecture and to develop a deliberative process for drafting provincial legislation in consultation with subject matter experts, stakeholders, civil society, and members of the general public. ${ }^{5}$ This section of the paper summarizes the legal framework for provincial councils' authority, describes the efforts to build council members' legislative capacity, and summarizes the results as of the end of LGP III in 2011.

\section{Iraq's Multiple Systems of Governance}

The Constitution of 2005 establishes two governments, which exercise national and regional governance. The character of the national government is federal with respect to Kurdistan, the nation's only current region; the Kurdish Regional Government (KRG) was recognized originally in the Constitution of 1970 and has its own article in the Constitution of $2005 .{ }^{6}$ Like the central government, the KRG possesses its own executive, legislative, and judicial branches and enjoys the constitutionally protected autonomy to govern its affairs within its regional borders. $^{7}$

The constitution creates two other systems of governance, subordinate to the national government: provincial and district (district is variously translated as municipal or local). The character of the national government in relation to the provinces is unitary. Provinces are defined as administrative units of the central government, which retains the authority to define or change their borders and, as Article 122 of the constitution stipulates, to regulate their affairs (see Box 1). The Law of Governorates of 2008 sets out the

\section{Box 1. Legal Authority for Provincial-Level Legislating}

\section{The Constitution of the Republic of Iraq of 2005}

\section{Article 122.}

Second: Governorates that are not incorporated in a region shall be granted broad administrative and financial authorities to enable them to manage their affairs in accordance with the principle of decentralized administration, and this shall be regulated by law.

Fourth: A law shall regulate the election of the Governorate Council, the governor, and their powers.

\section{The Law of Governorates Not Incorporated in a Region, Law 21 of 2008, as Amended by Law 15 of 2010}

\section{Article 2.}

First: The governorate council is the highest legislative and oversight authority within the administrative boundaries of the governorate and shall have the right to issue local legislation within the boundaries of the governorate so that it can carry out its affairs on the basis of the principle of administrative decentralization and in a manner that would not contradict the Constitution and federal laws.

\section{Article 7.}

The governorate council shall assume the following functions:

Third: Issue local laws, instructions, bylaws, and regulations to organize the administrative and financial affairs so that it can conduct its affairs based upon the principle of administrative decentralization and in a manner that would not contradict the provisions of the Constitution and federal laws. 
authorities of elected officials only. It does not grant authorities to provincial-level employees of central government ministries, leaving them to be regulated by other federal law.

Article 124 of the constitution recognizes a fourth governance system: that of the mayoralty (municipality) of Baghdad, the Amanat. This article assigns the Amanat jurisdiction for a discrete territory and for subject matter unique to that territory and stipulates that each of these should be regulated by a law. However, disagreements over the boundaries of the Baghdad municipality within the larger Baghdad province prevented the passage of a law for the capital.

The subordination principle contained in the constitution's supremacy clause and the hierarchy of law established the relationships among these four governance systems, with the constitution coming first, national or federal law coming second, and whatever provincial law might be issued coming third. This principle was controversial, however, as actors at the central and provincial levels contested the contours of provincial discretionary legislative space. ${ }^{8}$ Ambiguities in the law and differing political ambitions among those actors interpreting it fed these debates.

\section{Subordination to the Constitution and Federal Law}

One source of these disputes might have been a misunderstanding of the ministerial system of government in which government services are provided by central government ministries, organized vertically in geographically deconcentrated ministerial departments. ${ }^{9}$ This arrangement meant that "provincial government" comprised not just provincial councils but also staff of ministerial departments, members of the executive branch of the national government. CPA Order 71, which declared that the provinces "shall be organized on the basis of the principle of decentralization and the devolution of authorities" 10 and asserted that provincial councils "shall perform their responsibilities independently from the control or supervision of any ministry"11 encouraged elected officials to think of themselves as being in charge of basic public services. However, with the departure of the CPA and the return of sovereignty at the end of June 2004, provincial councils found themselves in an uneasy coexistence with provincial level departments of central government ministries.

The American occupiers' broad notion of federal decentralization, which went beyond simply administrative decentralization, became a sticking point in getting a draft constitution approved by the Transitional National Assembly in 2005 and in getting the Law of Governorates finally passed in February 2008. ${ }^{12}$ The Constitution of 2005, reverting to the description used in the Iraqi Law of Governorates of 1969, qualifies decentralization as "administrative." The Law of Governorates of 2008, which replaced Order 71, carries forward this restored qualification (see Box 1).

Once provincial elections were held in January 2009 and provincial council members were eventually seated by April of that year, challenges to the central government emerged, based on interpretations of the constitution and the Law of Governorates. Among the debates were differing interpretations of the subordination principle in the constitution and the meaning of "other federal law." Provincial council members conceded that while provincial councils were subject to the constitutional requirement to operate within the confines of "other federal law," they asserted that "other federal law" meant only legislation issued by the national parliament (the Council of Representatives, or COR).

This interpretation essentially reduced the entirety of federal law relevant to the provinces to just the Constitution of 2005 and the Law of Governorates. Yet an alternative reading of federal law would encompass anything with the force of law, including legislation-and also decrees from the prime minister and cabinet (or Council of Ministers), decisions of the Federal Supreme Court and Shura Council, and ministerial regulations. All of them constituted "other federal law," so the subordination principle expressed in the constitution and repeated in the Law of Governorates obligated provincial councils to follow, and the governor to enforce, national legislation, decrees, opinions, and regulation in effect within the territory of the province. The resulting conflict between elected provincial officials and the staff of 
provincial-level departments of central government ministries derived from this denial of concurrent jurisdiction in favor of a degree of provincial autonomy that depended upon an interpretation of the constitution and the Law of Governorates that not all actors agreed upon.

\section{Building Local Legislative Capacity While Avoiding Conflict}

With no prior experience to draw upon, and operating in newly created institutions with no history, provincial council members initially adopted local legislation in a spontaneous, ad hoc manner, often with little more deliberation than an impassioned speech. The resulting local laws were scarcely more than one- or two-sentence declarations (effectively resolutions) without clear statements of jurisdiction or means of enforcement. Within a few months of being seated, some provincial councils became objects of ridicule, losing legitimacy in the eyes of those who elected them and earning the contempt of the central government. In a few cases, other provincial councils succeeded in exercising new powers effectively. For example, provincial officials in Najaf established a tax on religious pilgrimage visits, which was not challenged by Baghdad despite policy statements from the Council of Ministers that provinces did not have taxation authority. However, the ambiguities in the constitution and the Law of Governorates, the resulting differing interpretations, and the underlying power dynamics of centralprovincial politics created an environment primed for contestation and conflict.

LGP III developed a capacity-building approach designed to support provincial councils in becoming effective deliberative and legislative bodies while avoiding clashes between provincial and central government actors. This avoidance of conflict was especially important following decisions by Iraq's top judicial forums, the Federal Supreme Court and the Shura Council, that neither would hear complaints from provincial councils against the central government. ${ }^{13}$ In the absence of a venue for the resolution of disputes between elected provincial and federal officials, ${ }^{14}$ LGP III steered its legislative strengthening assistance away from political controversies through applying the following set of criteria. Any proposed new law should:

1. Not conflict with the Constitution of 2005

2. Not attempt to regulate interstate/interprovincial commerce, including trade, raw materials, finished goods, labor, and persons

3. Not attempt to raise local revenue

4. Not be duplicative of a ministerial regulation on the subject

5. Not attempt to impose fines or criminal punishment

6. Be capable of enforcement by the governor, not the council.

The application of these criteria enabled provincial councils to concentrate on building their technical capacities for developing local legislation that was responsive to local needs and likely to earn local trust and respect without antagonizing central authorities.

\section{Bylaws and Committee Formation}

By the terms of the Law of Governorates, provincial councils were required to adopt internal bylaws within 30 days of being seated. By June of 2009, ten provincial councils had met that obligation (LGP II, 2009). Those initial bylaws, however, were highly diverse and idiosyncratic. Subsequently, provincial councils engaged in a process of almost constant revision of their bylaws as they gained experience and became aware of practices from other provinces through monthly information sharing workshops. The Shura Council promulgated its own model bylaws and urged provincial councils to adopt them. ${ }^{15}$ LGP III legal staff worked with numerous provincial councils to include practices and procedures developed over the life of the program into their bylaws, contributing to institutionalization across provinces.

Although the Law of Governorates does not mandate provincial councils to organize their work into committees, all of the bylaws they adopted did, so the array and composition of committees dominated the councils' early work. Without clear limits from the law, many provincial councils formed committees to address subjects they had no mandated authority to oversee (such as foreign relations). Further, in several provinces, the number of committees exceeded 
the number of individual council members so that everyone could be a chair. Organized to advance the personal agendas of individual provincial council members, many of these initial committees had never once met by the end of 2009, nor had they produced their own internal bylaws or issued reports.

More practically minded provincial council chairmen understood the dysfunctional nature of their committee structures, and LGP III worked with these reformers to restructure council committees to align with provincial-level ministerial departments and to amend provincial council bylaws to formalize this alignment. Restructuring committees was time-consuming because it required that provincial councils vote to amend their bylaws, but councils gradually configured their committees to match corresponding departments. ${ }^{16}$ These changes encouraged cooperation and information sharing among provincial councils and department officials.

\section{Legislative Histories and Calendars}

Establishing the foundations of the legislative function called for additional adjustment to council bylaws. For instance, when the provincial council members elected in 2009 were first seated, they conducted all of their business on the basis of either voice votes or a show of hands. They had no system for recording votes and none for the complexities of counting anything more than ayes and nays (e.g., abstentions, proxies). LGP III advisors helped them to routinely record votes for future reference, such as the legislative history of a bill. ${ }^{17}$ In addition, the advisors assisted provincial councils in creating their first legislative calendars, a prerequisite for organizing what would become an increasingly complicated docket of committee meetings, readings, and voting.

\section{Legislative Drafting Methodology}

LGP III drew heavily on the work of the United Nations Development Programme (UNDP) in crafting a methodology to assist provincial councils in writing local laws. The project relied on material produced by UNDP's Regional Bureau for Arab States Program on Governance in the Arab Region and in particular the legislative drafting manual it developed for the Council of Representatives. ${ }^{18}$ The resulting methodology directed council members to answer seven questions to help legislators understand the causes of a problem they would like to address and to make informed recommendations for a legislative solution (see Box 2). The introduction of these seven questions aided provincial council members in thinking more systematically about the underlying causes of a perceived problem and more deliberately about possible legislative solutions.

Answering these questions yielded a research report that could serve as the basis for a bill. LGP III advisors promoted a thorough, step-by-step process for developing a law in three stages:

1. A first draft created with the assistance of legal advisors and subject matter experts,

2. A second draft developed with input from civil society organizations, and

3. A third draft revised in light of feedback gathered from the public at an open hearing.

The application of this step-wise process of researching and developing a law with inputs from experts and affected stakeholders led to increased professionalization of provincial councils' legislative function, which also enhanced their reputations and legitimacy. Developing legislation in cooperation with community experts and ministerial department staff encouraged acceptance of the councils' legislative function under the Law of Governorates. The transparency of their hearings encouraged public participation in their deliberations and recognition of the laws they passed.

LGP III introduced the legislative assessment methodology gradually, beginning first with the equivalent of each council's Legal Affairs Committee. Efforts with the legal committees began in the fall of 2010, and LGP III advisors helped the committees to author or commission research reports and develop drafts of two bills apiece, so as to keep the workload manageable. The problems identified and the bills developed could be anything of the legal committees' choosing, but they had to follow the prescribed methodology. The focus of technical assistance was on the mechanics of law making, rather than on subject matter, following the criteria established to avoid unnecessary political confrontations with the central government. 


\section{Box 2. Assessing Legislation}

Existing Law: Is there a law that regulates legislative issues?

Compliance with Existing Law: Are the concerned parties aware of the current law? Do people comply with the existing law? If a law exists why is there little compliance? Do any of the following conditions exist?

- The written laws are confusing and poorly formulated.

- There are other contradicting laws.

- There are no options other than breaking the law.

- The existing law lacks transparency.

- The existing law is not mandatory or it contains loopholes.

Motives: What processes and procedures do individuals and institutions follow in their decision-making? If the committee can understand the motivation of individuals and institutions and the determinants of their decisionmaking, they will have an understanding of the reasons for their reaction towards the existing law. This understanding will enable the committee to change the law or write a new law in a way that meets the legitimate needs of the individuals and institutions involved.

Capability: Are the concerned parties capable of complying with the proposed solutions? Do the relevant parties have the required skills, knowledge and resources to behave in a different way?

Environment: What external factors combine with internal objectives to motivate law breaking? Are there conditions that create an opportunity for misbehavior? Can the new law change the existing environment to discourage law breaking? For example, if customs officers work without oversight and take bribes, is it possible for the law to require surveillance cameras, or unannounced visits from inspectors?

Beliefs: Is the problem behavior related to beliefs held by the parties involved? If so, what beliefs caused the need for legislation? Can personal beliefs be changed in such a way as to allow individuals to change behavior? How can beliefs be changed?

Consequences: What is the benefit or gain to individuals and institutions from violating the law? Is there enforcement? Who will discover violations? Are there any costs if the violation is discovered? What can be changed to make the concerned parties interested in compliance?

Source: Seidman \& Abeysekere, 2003.

This methodology meant that not every idea that a provincial council legal committee identified found a legislative solution. By September 2011, at the conclusion of LGP III, 200 draft bills had been developed, and just over 30 of them passed (see LGP III, 2011, pp. 15-16). The improvements in the quality of legislation were noticeable. For instance, where the average length of a law passed before LGP support was only a page, the average length of the laws developed after its capacity-building assistance expanded to eight pages, reflecting the application of the assessment methodology summarized in Box 2 and revisions made following public consultation. In addition, laws developed with LGP guidance were more substantively complete and procedurally democratic. They contained a statement of jurisdiction, were distinguished from other law on the subject, and had been developed through an open and transparent process in which councils drew on expertise from the community and gave citizens the opportunity to contribute to the result.

\section{Notice Requirements and Local Gazettes}

To take effect, laws had to be published in a provincial gazette, per the requirements of Article 12 of the Law of Governorates and in parallel with the requirement on national legislation adopted by the COR. When the council members elected in 2009 were seated, however, no provincial gazettes existed; councils organized before the application of the Law of Governorates had no responsibility to publish. The absence of a common means for publishing local law complicated its enforcement, as local legislation could not become effective until published. Despite the 
requirement that local legislation be promulgated in a provincial gazette, the Law of Governorates gives no further direction on the format of that gazette, or on the frequency of publication. In the absence of clear guidance, gazettes often became tools for political advancement.

Provincial council chairs were usually selected, like the prime minister, because they were the leaders of the party or coalition with the most number of seats on a council (or in concession to the party with the second most as a means of obtaining their votes for governor). Being among the strongest politicians in the province, these chairs often had their own agendas. Some coveted the governor's chair, some national office, and some just wanted to promote the interests of their party. Whatever their motives, many of them took advantage of the notice requirement for local legislation in the Law of Governorates to make the provincial gazette into an instrument of selfpromotion. For instance, one provincial council chair published a gazette in which every page featured his photograph. Rather than modeling his gazette on the example of the national version issued by the COR, he turned it into a propaganda device to advertise his accomplishments on behalf of his community.

Due to the dominance of such chairpersons and the absence of any pressure from the Shura Council or other central government body to standardize, the formats of provincial gazettes never converged in the way that bylaws did. They remained idiosyncratic and irregularly published. For example, Diwaniyah province published its first issue of Al Waqae'e in April 2011, more than two years after elections, though the first issue did contain all the laws passed by the provincial council in 2010 (LGP III, 2011, p. 35). In part because of these problems of politics and delay, numerous provincial councils established their own websites and published their laws electronically. This practical solution to the Law of Governorate's requirement left one question unanswered by the time LGP III closed: whether the constructive notice by electronic publication on a website instead of paper publication is adequate to satisfy the requirements of the law.

That subtlety aside, having assisted Legal Affairs Committee members through the comprehensive legislative methodology, LGP III advisors coached from the sidelines as legal committees instructed another committee (and then a third) through the same process. Through this training-of-trainers approach, program staff progressively took a backseat role. In the final months of the program in the fall 2011, they urged provincial councils to finish the job by amending their bylaws one last time.

\section{Institutionalizing the Process of Legislating}

In the spring of 2011, knowing that LGP III would be ending in the fall, technical staff began gathering everything they had learned over the previous two and a half years into a series of practice manuals. LGP III advisors suggested that provincial councils include triggers in their existing bylaws, making reference to the stepwise manuals mandatory for performing the five cardinal functions of the provincial councils: legislating, planning, budgeting, spending, and monitoring/oversight. Numerous councils adopted these procedures; Babil, Diwaniyah, Najaf, Kerbala, Muthanna, and Wasit made reference to the manuals mandatory for ordinary council business. As a result of LGP III assistance, provincial councils in the 14 provinces outside the KRG continued to research and draft legislation responsive to the needs of their citizens and in subordination to the constitution and other federal law for more than a year following the termination of the program, still using the assessment methodology they learned from LGP III advisors.

\section{Provincial Planning and Capital Investment Capacity}

The provincial councils' planning, budgeting, and spending functions evolved with the changing legal architecture of the Iraqi state from the CPA occupation period to the adoption of the 2005 constitution and the 2008 Law of Governorates. Provincial councils' authorities and responsibilities related to these functions grew in complexity and sometimes provoked tensions with the deconcentrated service delivery departments that shared governance responsibility with locally elected officials and with the central government. LGP assisted elected provincial officials in clarifying their relationships with other government actors and 
establishing systems and processes to build their capacity to fulfill their role in capital investment budgeting and management.

As administrative units of the central government, provinces (not including the KRG) were funded through a unified budget. CPA Order 95 laid out the process that the Ministry of Finance (MOF) retained after the return of sovereignty and followed in proposing the budget, and that the COR employed in adopting an annual budget law. It consisted of three parts: operations and maintenance (O\&M), ministerial investment, and a special fund to finance projects in the provinces-the Accelerated Reconstruction and Development Program (ARDP).

Once a year, following publication of the annual budget law, the ministry issued instructions in how that law was to be interpreted. Although CPA Order 95 required that budget laws be passed by December 3 , they were frequently delayed but generally adopted by the end of the first quarter of the calendar year that they financed. MOF instructions then followed, usually by the end of the second quarter. These instructions often imposed short deadlines for the submission of O\&M requests from all government bodies. In the provinces, those government bodies included provincial-level departments of central government ministries, the provincial council, and the governor's office, all of which were required to submit separate O\&M requests.

The deconcentrated departments submitted their budgets to their respective ministries, which aggregated them before submission to the MOF. Provincial councils, in contrast, submitted their O\&M requests directly to the MOF, since the Iraqi Minister of State for Provincial Affairs lacked the authority of a traditional Minister of Local Government, who would be responsible for overseeing not only the administration of the provinces but also their funding. This absence of a champion with equivalent ministerial status seemed to weaken the provincial councils relative to the sectoral ministries when it came to the amount of O\&M funds allocated. Provinces depended on the MOF for almost all of the money they received, used the chart of accounts prescribed by the ministry, and were able to execute only those contracts that the Ministry of Planning and Development Cooperation (MOPDC) approved and the MOF agreed to include in its draft budgets for the next year. The independent authorities of the provincial councils and governor's offices remained significantly constrained, although they had some discretion regarding their annual ARDP allocation, whose amount was based on population and spending priorities determined by public service needs (LGP II 2008a).

\section{Struggles with Fiscal Policy Reform}

A key post-invasion CPA reconstruction objective was to build legitimacy for the new government by creating subnational capacity to deliver services to the population to improve their lives (LGP 2005). CPA Order 71 declared that this "Order is designed to improve the delivery of public services to the Iraqi people and make the Iraqi government more responsive to their needs." 19 In keeping with the classic principles of decentralization, the CPA envisioned a governance system where revenue raising and spending authority would be delegated to the provinces. However, available revenues from local property taxes or market fees were insufficient to fund services, so provinces, and their cities and towns, depended almost exclusively on central transfers. ${ }^{20}$

The Constitution of 2005 states that the provinces "shall have independent finances," and two articles opened the door for new intergovernmental fiscal relations. First, Article 65 calls for the creation of an upper house of the national legislature. Known as the Federation Council, it was to comprise representatives of the "regions and the governorates that are not organized in a region." Second, Article 106 calls for the creation of a public commission, composed of experts from "the federal government, the regions, and the governorates" to (among other things) "guarantee transparency and justice in appropriating funds to the government of the regions and governorates that are not organized in a region." Considering the nation's wealth of natural resources, Article 112 provides that revenues from the production of oil and gas are to be distributed "in a fair manner in proportion to the population distribution in all parts of the country."

LGP II advisors encouraged central government officials to implement these constitutional promises. 
For instance, in late 2007, LGP II, working through a then-informally organized Iraqi Local Government Association (ILGA), persuaded the MOF to hold its first ever budget hearing between the ministry and elected provincial officials on the draft 2008 Annual Budget Law. Following the successful conduct of the hearing, the advisors developed a policy document emphasizing tax- and revenuesharing that they presented to the ILGA in August 2008. They then helped the association draft a bill, which would have established the Article 106 public commission. Although it was presented to the COR, that bill was never adopted, and the commission (like the Federation Council) was not formed. In February 2008, the ILGA and LGP II advisors held an intergovernmental fiscal relations conference in Najaf to try to build a constituency for reform, but made little progress. ${ }^{21}$ The national budget remained solidly under central control.

\section{Sources of Funding for Capital Projects}

Governments around the world fund capital investments in one of two ways: debt or equity. Since provincial councils and governor's offices were not allowed to issue bonds, the remaining option was equity financing. Elected officials at the provincial level had three sources for funding capital projects: international, national, and local sources of funds.

Prior to the invasion, Iraq received funding from the United Nations-administered Oil for Food program, and after the invasion a variety of international funding sources emerged. The Commander's Emergency Response Program (CERP) provided quick-response resources to address immediate needs. It was funded initially from confiscated assets of the former regime and continued with U.S. funds once the Iraqi monies were exhausted. In November 2003, the U.S. Congress authorized $\$ 3.24$ billion for security and law enforcement, $\$ 1.32$ billion for justice and public safety infrastructure, $\$ 5.56$ billion for the electric sector, $\$ 1.89$ billion for the oil infrastructure, and $\$ 370$ million for roads, bridges, and construction. The initial ceiling amounts of discretion ranged from $\$ 200,000$ for colonel-level commanders to $\$ 500,000$ for brigadier/major general-level commanders. ${ }^{22}$ The CPA established a temporary Local Government Fund (LGF) to offer nascent provincial councils some independent funding so they could begin learning how to manage money on their own and earn the trust of the central government.

Along with these large programs, provinces had access to a variety of smaller sources for capital projects. These included Rapid Response Grants in the first phase of LGP, ${ }^{23}$ a refurbishment fund in LGP's second phase, ${ }^{24}$ and the matching funds of USAID's Community Action Program, along with numerous others up until the closure of Provincial Reconstruction Teams and the withdrawal of U.S. forces in $2011 .{ }^{25}$

Once Iraq regained sovereignty in June 2004, national sources of funding capital projects began to replace international ones. In 2006, the central government created the Accelerated Reconstruction and Development Program (ARDP) (see Johnson \& Silva-Morales, 2011). Initially provincial councils were given responsibility to manage the program, like its predecessor LGF. In 2007, however, ARDP management was transferred to the governor's offices. Program funds totaled US $\$ 2$ billion in 2006; by 2007, because of a falling exchange rate and unspent monies carried forward from the first year of the program, that figure had increased to the equivalent of US $\$ 4.4$ billion. In 2008 , the allocation rose to $\$ 3.7$ billion, with a US $\$ 2.1$ billion carry-forward for a total of US $\$ 5.8$ billion (LGP II 2009, p. 26). In addition to this reconstruction fund, with Article 43 of the 2010 Budget Law, the central government increased the total available to those provinces with natural resources. This "petro dollar" account greatly expanded the potential revenue of oil- and gasproducing provinces.

As noted previously, provinces were almost completely dependent upon central government allocations, though provincial authorities are entitled by the Law of Governorates to raise some local revenue. For example, in addition to the Revenues of Municipalities Law 130 of 1963, a 2008 Federal Supreme Court advisory opinion held that a province could collect local taxes. Issued in response to an inquiry from Najaf, in practice the opinion seems to have allowed taxes on pilgrims to religious sites in that province. Attempts by other provinces to generate own-source revenue through local taxes 
were struck down by successive governments and the Council of Ministers. ${ }^{26}$

\section{Reforming Capital Planning and Budgeting}

LGP II advisors first worked with councils in 2007 and 2008 to develop a planning process and a document called the Provincial Development Strategy to serve as the foundation for capital funds allocation from the various sources outlined above. ${ }^{27}$ Article 7 of the 2008 Law of Governorates mandated that each provincial council identify its priorities and "outline its policies and strategic development plans." Widespread adoption of the Provincial Development Strategy model led to its acceptance as the operational expression of Article 7.

\section{Planning for Capital Projects}

Each year, the province prepared its Provincial Projects List, which was a request to the Ministry of Planning and Development Cooperation (MOPDC) for approval of capital projects to be included in the draft national budget prepared by the MOF for submission to the COR. In identifying service delivery projects for inclusion in its Provincial Projects List, a province relied on an annual Provincial Development Plan. That plan was derived from a five-year Provincial Development Strategy. ${ }^{28}$

The Provincial Development Strategy was both a process and a document (see LGP II, 2007c). The process consisted of three phases-formulation, implementation, and institutionalization-and emphasized participation by the public, elected officials, and departments. The resulting strategy document served as the strategic guide for the Provincial Development Plan, which in turn was used to prepare the annual Provincial Projects List for the MOPDC. By comparing actual with expected results, the province could (theoretically) adjust its strategy and plans each year to increase the efficiency and effectiveness of provincial efforts to improve public service delivery.

The Provincial Development Strategy was intended to be integrated with the National Development Strategy. However, this intent was incompletely realized during LGP's lifetime. Provincial actors did not play a significant role in national planning exercises, which were dominated by central government officials. ${ }^{29}$ However, annual acceptance by the MOPDC of each province's Provincial Development Plan resulted in the de facto incorporation of provincial plans into the National Development Strategy.

\section{Budgeting for Capital Projects}

The funding request that accompanied the Provincial Projects List consisted of two broad categories: budget formulation and budget execution. To cost out capital projects, provincial officials had to gather data and make funding projections, and they also had to determine how best to use their limited funds, adding the O\&M costs of provincial government institutions on top of the estimated cost of capital projects.

Once projects in the Provincial Projects List were approved by central ministries and money from the federal budget allocated for them, the provinces were under pressure to spend. Provinces faced some challenges to executing their budgets in a timely manner. Because spending authorization expired at the end of each calendar year, delays in tendering and disbursement caused unspent balances to linger, meaning the province ran the risk that the unspent balances would not be reauthorized by the MOF for the subsequent year. However, cutting corners to speed expenditures increased the risks of waste, fraud, and abuse, which introduced further delays as problems were detected and corrected. ${ }^{30}$ Close monitoring of approved project implementation was therefore necessary both to increase budget execution rates and ensure a match between expected and actual results.

\section{Monitoring of Capital Projects}

Monitoring and evaluation began with the project announcement and request for bids by the governor. Both the provincial council and the governor's office cooperated in monitoring and evaluation, with support from LGP. Joint oversight and timely information increased the timeliness of error detection and quality of results. Provincial Planning Monitoring Reports tracked progress against service delivery goals and provided a basis for adjusting implementation. The provincial council and governor's office used the reports to identify whether delays in implementation were due to unrealistic 
expectations in the Provincial Development Strategy/ Provincial Development Plan, the limited capacity of staff or contractors, or other factors.

\section{Data and Decision Making}

Both the large amounts of money pumped into Iraq during the reconstruction period and the haste with which that money was spent attracted criticism (see, for example, SIGIR 2013). The risks involved with the massive influx of funding were recognized at the time. To help to mitigate them, LGP encouraged provincial officials to adopt stronger planning, monitoring, and oversight processes. These all depend upon more and better quality data, information, and analysis. LGP trained elected officials (and corresponding departments) in data collection techniques and spatial relationship map making, and it established a standard template for strategic development planning. Once the planned projects were approved and funded and implementation underway, LGP assisted elected officials with monitoring service delivery performance and financial monitoring of the investments.

As noted above, LGP's development of the Provincial Development Strategy methodology predated the 2008 Law of Governorates. However, the methodology became institutionalized in that the provincial councils' legal obligation to determine the strategic direction of the province came to be understood by both provincial councils and the MOPDC as a Provincial Development Strategy, Provincial Development Plan and an annual Provincial Projects List. The methodology changed the way long-range planning was conducted and provided a framework for data-based decision making. That emphasis on data, in turn, provided the impetus for LGP to assist departments and elected officials in gathering better quality data.

Among the means for collecting better data were surveys and geographical information system (GIS) tools. Citizen surveys began in the early days of LGP's first phase. For instance, an assessment of basic services in 2003 found electricity, water, waste water, and solid waste collection to be in disarray and, unsurprisingly, public satisfaction levels to be very low. ${ }^{31}$ The neglect of public investment for so many years had taken its toll, and both project surveys and external evaluations repeatedly confirmed widespread citizen frustration with the government's provision of even the most basic of services. ${ }^{32}$

Citizen dissatisfaction with the limited availability of electric power sparked demonstrations in Basrah in the summer of 2010. Without regard for the fact that elected officials at the provincial level had no authority over the generation or distribution of electricity (that being the responsibility of the central electricity ministry), protesters gathered in front of the provincial hall. Unfortunately, local security forces shot and killed two protesters, leading to popular indignation. To avert further unrest, the prime minister sacked the Minister of Electricity. In the rest of the country, similar protests inspired by the events in Basrah were boisterous but without fatalities. They all communicated the same message: the population expected to be better served.

\section{Citizen Satisfaction Surveys}

Incidents like the electricity protests encouraged local governments to consult citizens on service needs. In 2010, LGP III helped provincial water departments to pilot a water users' satisfaction survey, using random sampling for respondents. With the monitoring staff from Baghdad and provincial offices, LGP III designed questionnaires and a data collection schedule. LGP III approached staff of the departments and the governor's offices, who initially viewed the proposed survey with suspicion, doubting that anyone would talk to them. In Baghdad in particular, where acts of violence were still common, the survey designers were told that no one would open their doors to strangers. Other arguments against the surveys included the presumption that "good Muslim women" would never talk to strangers. A third argument was that it was summer and the staff did not want to go door to door in the heat.

The survey began with neighborhood pilots. LGP III appealed to the political instincts of the governors or provincial council chairmen and persuaded them to endorse a random sampling of their neighborhoods. With their support, water department and governor's office staff, along with LGP advisors, went door to door in numerous provinces. To the surprise of just about everyone, and especially the naysayers, the survey teams were received enthusiastically. In 
Baghdad, for example, people invited them into their homes and offered them fruit and cold drinks.

The resulting summary reports detailed the problems and causes of poor water quality. For instance, during the occupation, low water pressure had been addressed by the installation of additional or higher capacity pump stations. However, the water users' survey revealed that in some neighborhoods, low water pressure was attributable to leaky pipes, which explained why new pump stations had been so ineffective in increasing water flow into residences. The surveys not only better identified the cause of service problems but involved citizens in their solution. This engagement reinforced the Provincial Development Strategy methodology and demonstrated to local officials the benefits of citizen consultation. ${ }^{33}$ As one elderly woman commented to the survey team: "I've lived in this neighborhood all my life and this is the first time anyone from the government has ever asked my opinion." By simply asking questions, local government staff collected better quality information than they had found on their own and garnered public support and legitimacy for local government (see Brinkerhoff, Wetterberg, \& Dunn, 2012).

The information collected in the water users' survey was inherently subjective, being based on a small sampling of individuals in select neighborhoods. A more objective means of identifying service delivery issues was necessary to complement the surveys, and that complement came in the form of information technology.

\section{Geographic Information System}

For all of its emphasis on public participation, the Provincial Development Strategy methodology presumed a solid baseline. Unfortunately, however, most provincial administrators had never had any responsibility for service delivery planning before and had no relevant information about services. The reasons for this absence included careless recordkeeping, combined with an almost total reliance on manual paper systems, much of which was lost in the war and the looting that flared up occasionally after it. While large amounts of documentation were destroyed in the war and its immediate aftermath, later protests and demonstrations also contributed to their destruction.

Violence was not the only explanation for Iraq's poor quality of baseline data for urban planning. Far more destructive were the ordinary depredations of time as well as departmental reluctance to share information. Because of all these factors, the usual way of finding the location of buried water or sewage lines was to find the oldest resident of a neighborhood and ask. For service delivery to improve or for small projects to correct shortcomings, the basic infrastructure had to be identified, and once identified it needed to be preserved.

Recognizing this need, LGP engineers in Basrah, working with provincial department staff, collected and saved old maps. Rolled and stacked loosely on shelves in the property registry office, the maps were hand-drawn and showed plats with numbers crossreferenced to a manual entry title registry. Some of the maps dated back to the Ottoman period, and many were in various states of disrepair. Because of their poor condition and the way they were stored, project management at the time referred to them as being like the Dead Sea Scrolls, and indeed when staff began scanning fragments and reassembling them like a digital jigsaw puzzle, the metaphor seemed appropriate. But as maps emerged from the disconnected pieces, their utility beyond mere map preservation likewise became clear.

With the plots of land in a neighborhood serving as a base map, layers of public service infrastructure could be added. For example, a separate map showing the location of power, sewer, and water lines could be layered onto the base map, and through the use of GIS technology, the spatial relationships could be shown either separately or in the aggregate. Once identified and recorded in GIS, the exact location of a service line would be known and preserved because the resulting digital map could easily be reproduced.

In addition to establishing the location of service lines, GIS provided a baseline for planning. From the maps, population growth trends could be seen and with them needs anticipated. Data from GIS, along with data gathered from public surveys and public participation events, guided the creation of Provincial Development Strategies, Provincial Development 
Plans, and the list of requested investment projects. Having introduced the technology and worked with provincial departments to demonstrate its utility, LGP passed implementation to their staff, who continued improving base maps, adding neighborhoods and service lines.

\section{Feasibility Studies}

The MOPDC expected both technical and economic feasibility studies for every project on a governor's office's list of prioritized projects, but opinions differed as to what information the ministry expected in each study. Preparing the studies added to the already considerable amount of time it took to gather the information necessary to complete a Provincial Development Strategy and Plan, and provincial councils and governor's offices complained about the MOF's tight deadlines for submission of their annual O\&M requests. However, preparing them actually took very little time, so they either did not miss the deadline at all or did not miss it by much. In contrast, the MOPDC's deadline for submission of Provincial Projects Lists with completed feasibility studies was often missed by months.

Part of the problem was political, and it may explain why access to ARDP monies was taken away from provincial councils in 2007 and given to governor's offices. Before that shift, the number of projects that provincial councils requested funding for was typically over 100 - far too many to be approved, funded, or realistically implemented within the limited time of a calendar year. That, along with the MOF's reluctance to approve funding requests and the effective absence of any banking system, prevented money expected by the provinces from being transferred to them in time to implement projects. Provincial council members took advantage of this inefficiency to promise their constituents mini-projects that they never expected to be completed. The long list of incomplete projects gave the central government more evidence that provincial officials lacked the capacity to be given more authority. Provincial officials felt that the central government was actively blocking local-level development investments in order to maintain central dominance. Lack of implementation progress created motivation on all sides for changes.
As a result of transferring responsibility over the ARDP to the governor's offices, the number of projects proposed for funding dropped significantly, as did pet projects intended to curry favor with individual council members' constituents. Governors, who according to the Law of Governorates are elected by provincial council members rather than by the voting population of the province, do not have the same incentives as councilors to make promises to particular constituencies. In principal at least, they have responsibility for the entire province, and thus need (theoretically) to balance the parties and factions on the council and broker compromise.

What also seemed to reduce the number of projects proposed, and improve their quality, was the MOPDC's insistence that proposals include feasibility studies. As with most central government requirements, the imposition of a feasibility study for proposed projects gave more evidence to those who saw every requirement as an assertion of centralized control. But this requirement dated from a 1980 law, and simply reasserted standards that had previously existed but had been ignored during the "easy money" days of the Coalition Provisional Authority occupation. As the Provincial Development Strategy process matured, provincial councils grew more sophisticated in how they undertook development planning and recognized the benefits of assessing project feasibility.

However, opinions differed on the appropriate content and length of the studies. The form used by the ministry was 42 pages long and required information that could not be easily obtained. LGP staff in Basrah looked at the old law and created a short form to satisfy its requirements. The form answered all the questions required and facilitated the collection of information needed to complete the longer form. Then they convened a meeting of department staff, the governor's office staff, and members of the provincial council Essential Services Committee who over the course of a couple of days together completed the short forms for all but one of the projects identified by the governor's office for the coming year.

In parallel, the LGP planning advisor opened a dialogue with the MOPDC's Director General for 
Planning, who had the ultimate authority to approve projects submitted by the provinces. She agreed to the feasibility study short form, recognizing the efficiencies in using a standardized set of questions. She personally introduced the new format at a national planning conference in Babylon in August 2010 and encouraged the provinces to submit a feasibility study for every project proposed.

\section{Service Delivery Performance Measures}

To facilitate effective service delivery implementation, LGP engineers worked with the staff of the governor's office, members of the provincial council Essential Services Committee, and department staff in establishing a baseline for standards for Service Delivery Performance Measures. Because the Law of Governorates gives the governor's office the authority to compel reports from service departments, and it gave the provincial council the authority to propose senior officials for appointment to the departments (and empowered them to remove underperforming ones), elected officials required reliable performance information. The Service Delivery Performance Measures baselines provided standards against which to measure the performance of departments and by implication their senior managers. The baselines also give the governor's offices a basis for judging the improvements gained from ARDP projects.

\section{Project Financial Tracking}

While tangible improvements in services might only be discernible upon project completion, governor's office staff needed to keep track of the money being expended while those projects progressed. LGP advisors developed the Governorates Accounting and Project Tracking Information System. This software was intended to give provincial governors a means of financial monitoring by producing running balances for each contract let. Although the idea was enthusiastically embraced and versions of the software were customized to the expressed wants and needs of individual provinces, the system was only as good as the data entered into it. A shortage of data entry clerks in several provinces led LGP to hire temporary staff to do data entry, but continued departmental reluctance to share information limited the completeness of the program's information.
These complications aside, Najaf province adopted the system, entered data for old, incomplete, and current project themselves without requesting outside assistance, and most importantly became the first province in the country to issue a trial balance with the system on October 26, 2008 (LGP II, 2009). As other provinces followed, the software helped the governor's office maintain close control over projects in implementation in the province. The system was transitioned to the control of the provinces near the end of LGP III in mid-2011, where it continued to be recognized as a model of financial monitoring of investment projects.

\section{Planning and Budgeting Capacity Outcomes}

Over the course of its years of implementation, LGP assisted elected provincial officials in expanding their financial and managerial discretion and authority within the architecture created by the Iraqi constitution and the Law of Governorates. In its first phase, LGP encouraged the Minister of Public Works to float an ultimately unsuccessful pilot to transfer responsibility for basic services to the control of the provinces. ${ }^{34}$ LGP II promoted "intergovernmental fiscal relations," although by the time the Law of Governorates came into effect, centralizing political and bureaucratic forces were in the ascendancy and provincial actors' dreams of fiscal autonomy faded. Those forces notwithstanding, LGP's capacitybuilding support on basic public administration led to improvements in the quality of provincial capital investment projects, in service delivery data collection and analysis, and in the ability of provincial councils to respond to their constituents.

The Law of Governorates' grant of authority for provincial councils to determine their strategic direction was widely understood to mean the Provincial Development Strategy, and the MOPDC accepted the project lists derived from that strategy as the documents required for the ministry's approval of capital projects. As a consequence, the provinces and the ministry shared common expectations, which led to faster approval and better execution of provincedefined capital projects. For instance, in 2010, ten provinces met the submission deadline for their Provincial Projects Lists, while only three had done so a year before (LGP III, 2011, p. 18). The average 
budget execution rate for ARDP-funded projects in 2010 was 67 percent, with three provinces-Kerbala, Baghdad, and Anbar-executing 100 percent of their ARDP monies and Dhi Qar, Maysan, and Najaf executing over 90 percent of theirs (LGP III, 2011, p. 22; see also Natali, 2010). In comparison, an average of around 25 percent of capital or investment money was allocated to central ministries. So, LGP's assistance arguably contributed to building the capacity of elected provincial officials to fulfill their planning, budgeting, and spending functions more effectively than most central ministries.

Subsequent decisions changed responsibilities for provincial development planning following LGP's completion. A directive issued in the summer of 2012 by the prime minister and the MOPDC created provincial planning and development councils and placed them under the control of provincial governors. Although the terms of the directive are not entirely clear, it appears to charge these newly mandated committees with development of Provincial Development Plans, and Provincial Projects Lists. These responsibilities formerly belonged to provincial councils, based on the authority given to them by the Law of Governorates to set the strategic direction of their province. The new procedure implied by the memorandum seems to amend the law by shifting that responsibility to special committees, reporting to the governor.

\section{Lessons Learned}

In some respects, the state-building enterprise in Iraq remains an outlier in the panoply of international stabilization and reconstruction interventions undertaken by the international community. Driven by U.S. policy and executed by a U.S.-dominated coalition, the intervention led to the design of an Iraqi state that, as Lake (2013, p. 294) characterizes it, "was quite literally 'made in the USA.' " Yet the effort reflected many of the precepts and practices of international post-conflict peace-building operations, core among which is the creation of an institutional architecture incorporating neoliberal democratic governance structures and values (see Paris \& Sisk, 2009). Thus, while we acknowledge that LGP was a product of a U.S. policy agenda that many consider to have been a failure, we nonetheless consider that the experience we have recounted here holds relevant lessons for future interventions. These can be divided into lessons related to the legal foundation of the state and decentralization, and those related to governance capacity.

\section{Constitutional Frameworks}

Constitutions establish the governing principles that undergird the legal architecture of the state and embody societal norms, values, and aspirations. In deeply divided post-conflict societies, constitutionmaking tends to pave over divisions with generalities and ambiguities in order to craft a framework that all actors involved can agree upon (Belman \& Lerner, 2007; Samuels, 2009). In the case of Iraq, those divisions derived from the differences between the views and intents of the CPA officials and those of the Iraqi participants in drafting the constitution, as well as conflicting views among different Iraqi ethnic and political groups. It is beyond the scope of this paper to comment on the success of constitution-making driven by international actors. ${ }^{35}$ However, the lesson here is that the ambiguities in the constitution need to be worked out through the political process and the subsequent elaboration of policy and legislation, which places a premium on the development of policy-making and legislative skills among elected officials and executive agency leadership. The extent to which a post-war government abides by the new constitutional framework is one benchmark of success in rebuilding governance systems.

\section{Implementing Decentralization}

The Law of Governorates frames the institutional architecture for decentralization in Iraq, and that architecture is still relatively new. Decentralization is a long-term process that usually consists of the classic two steps forward and one step back, and is never "finished" in a definitive sense (see Brinkerhoff \& Johnson, 2009). In decentralized governance systems, intergovernmental authorities and responsibilities are constantly subject to revision and renegotiation. The experience with the provincial councils demonstrates that the skills and behaviors of provincial council members have an impact upon center-province relations and upon how local citizens view their elected officials. Improved legislative capacity has the 
potential to contribute to enabling decentralization to provide its theorized benefits in terms of service delivery effectiveness, subnational autonomy, responsiveness and accountability, and increased legitimacy.

Iraq's decentralization is partial and incomplete. On the political side, as of this writing, two rounds of local elections have been held and provincial officials have gained governing experience and some legitimacy (by virtue of having been elected) operating in a decentralizing setting. However, provincial councils remain weak relative to centrally appointed actors. Regarding fiscal/financial decentralization, although Article 44 of the Law of Governorates opens the door to local revenue generation, in practice almost all provincial funding comes from central government allocations. Administrative decentralization (not surprisingly, given the constitutional and legal framework summarized above) is most accurately characterized as deconcentration, where provincial administrative and service delivery actors operate under the authority and direction of their parent central ministries.

The government is under increased pressure from citizens to deliver services, jobs, and security. While the Iraqi government's need to respond could create some modest incentives to move beyond deconcentration, we see the pendulum swinging further toward centralization. In terms of service delivery, the political and bureaucratic dynamics are likely to continue to favor executive branch dominance from the center that restricts the roles and responsibilities of the provincial councils. The 2012 ministerial directive removing by executive fiat the authority of elected councils to oversee capital project planning, which significantly weakens their relevance, is a case in point.

Several other factors signal dim prospects for decentralized governance going forward. First is the lack of institutions empowered to clarify centerprovince relationships, remove inconsistencies or contradictions, or adjudicate disputes. Nominally, institutional space exists for entities that take into consideration the interests of the provinces or resolve disputes between the various government bodies at the provincial level, but as our narrative shows, in practice they are largely absent. The High Commission for Coordination Among the Provinces, called for in the Law of Governorates, Article 45, has met only three times since its creation in 2009 and has yet to form a secretariat. The upper house of parliament called for in the constitution has never been formed, and the Minister of State for Provincial Affairs has no rulemaking authority. Neither the Federal Supreme Court nor the Shura Council is authorized by its statutes to hear cases from provincial councils. These institutional gaps bode ill for clarifying legal ambiguities and resolving disputes in favor of provincial actors.

Second, although the debates about decentralization are conducted ostensibly around constitutional, legal, and administrative issues, the underlying dynamic is contestation for political power and control. Recent upticks in violence have highlighted the fragile nature of the elite pact that supports the tenuous stability in Iraq at present. The Maliki government has shown a growing tendency to consolidate state control at the center. The prime minister and his cohorts have few incentives to empower provincial actors who could become political rivals through making more progress on decentralization. Sectarianism, long used by Iraqi actors to advance their interests, remains a potent political force (see Ismael \& Ismael, 2010, and Dodge, 2012). ${ }^{36}$

\section{Governance Capacity}

Whatever form of governance system exists, and/or is rebuilt, in a conflict-affected country, the ability of the state at various levels to fulfill basic public administration functions is key to attaining stability and a return to positive state-society relations (see United Nations, 2010). Post-invasion Iraq had a weak local public administration: local public sector actors had little experience in decision-making, and the legacy of decades of central control and intimidation had conditioned them to avoid taking initiative. LGP's capacity development efforts with provincial councils, governor's offices, and the deconcentrated units of sectoral ministries helped those actors to master the "mechanics" of the legislative process, constituency building and responsiveness to citizens, service delivery needs assessment, planning, and 
budgeting. A simple but important lesson, then, is the reaffirmation that "public administration matters, and when the gap between capacity and expectations is large, it matters a lot" (Brinkerhoff, 2008, p. 119). This gap remains a serious challenge to the Iraqi state as citizens' patience with lack of services, jobs, and security grows thinner. Whether the political dynamics in today's Iraq will enable the emergence of a viable social pact that includes effective service delivery, economic development, and improved safety and security is an open question (see, for example, Bouillon, 2012).

A related lesson concerns how LGP approached governance capacity development. Capacity development for the provincial councils needed to take account of the political realities affecting the councils, their members, and other stakeholders, both provincial and national. Staff infused political understanding into their technical assistance, informed by in-depth knowledge of the constitutional and legal framework along with recognition of the contestation for power inherent in the decentralization process. Increasingly over the life of the program, Iraqi experts, and not expatriate LGP staff, provided the hands-on capacity development assistance to provincial officials. This approach enhanced the success of that assistance and contributed to the sustained use of the public administration tools and methodologies introduced. It exemplifies what has been termed working "with the grain" to achieve institutional reforms, which takes into account-and works with-local actors' incentives to pursue change (Booth, 2011).

\section{Concluding Thoughts}

While one lesson from LGP's experience is that public administration matters, the "bigger picture" lesson for post-conflict stabilization and reconstruction may well be that be that technical interventions, such as in public administration, will only be effective if they account for politics. Governance templates for stabilization and reconstruction have tended to treat both politics and public administration as amenable to technical interventions and solutions, applying an internationally recognized good governance toolkit (see U.S. Institute of Peace \& U.S. Army Peacekeeping and Stability Operations Institute, 2009). All three phases of LGP, as designed by USAID, incorporated elements of that toolkit. Our story of LGP's local legislative strengthening activities and its support for provincial planning and budgeting illustrates how political contestation between actors at the center and in the provinces penetrated the realm of public administration. The constitution, laws, regulations, procedures, and budgets were the "weapons" employed in the competition for influence, authority, and power. As we remarked above, the extent to which LGP achieved a degree of success with its public administration capacity building derived in no small measure from recognizing, and working within, the political dynamics at play in postwar Iraq.

Stabilization and reconstruction interventions will necessarily confront the dilemmas inherent in externally assisted state building where outsiders have limited control over ultimate outcomes (Paris \& Sisk, 2009). In the governance arena, we consider that getting smarter about recognizing and incorporating the interpenetration of politics and administration is critical to supporting transitions that contribute to achieving peace, stability, and an effective state. 


\section{Endnotes}

1. "Big D" democracy commonly refers to the formal system of democratic institutions: elections, political parties, judiciaries and courts, and national legislatures (see NRC, 2008).

2. The Iraq Local Governance Program began in April 2003 and concluded in September 2011. Total funding from USAID was $\$ 807$ million (SIGIR, 2013, p. 109). LGP consisted of three separate phases: LGP I (official title: Iraq Local Institutional Support and Development Program, duration: April 2003-May 2005) focused initially on immediate post-conflict service delivery capacity and restoration of the population's access to basic services. Along with service delivery, LGP I supported the creation of transparent and accountable subnational governance structures and facilitated the development of civil society organizations' advocacy capacity. In early 2004, USAID tasked the program with organizing nationwide civic dialogue sessions to increase democracy awareness in preparation for Iraq's transition to sovereignty later that year (see Local Governance Program, 2005; Brinkerhoff, 2008).

LGP II (official title: Strengthening Local and Provincial Governance Program, duration: May 2005-January 2009) had an overarching objective to establish and strengthen the conditions, institutions, capacity, and legal and policy framework for a democratic local governance system in Iraq. The program targeted its support to provincial officials, elected and appointed, and operated through Provincial Reconstruction Teams, which integrated reconstruction assistance from the U.S. military, the State Department, and USAID. The principal purpose of LGP III (official title: Iraq Local Governance Program-Phase III, duration: January 2009-September 2011) was to support implementation of the Law of Governorates Not Incorporated into a Region, passed in 2008. LGP III aimed to strengthen the responsiveness and effectiveness of provincial councils and governors (see LGP III, 2011). RTI International was the lead contractor for the three phases of LGP.

3. Decentralization concerns the allocation between center and periphery of (1) power, (2) authority, and (3) responsibility for political, fiscal, and administrative systems. The most common definitions of decentralization distinguish variants along a continuum where at one end, the central government maintains strong control, with limited power and discretion at lower, subnational levels (deconcentration) to progressively decreasing central control (delegation) and increasing local discretion at the other (devolution). The devolutionary end of the continuum is associated with more democratic governance. In principle, accompanying the transfer of authority and responsibility from the central to subnational governments and the expanded discretionary space for local government decisionmaking is a shift in accountability. Upward accountability to the center is supplemented with, or in the case of devolution, largely superseded by, downward accountability to citizens. In federalist systems of government, the distribution of governing powers among different levels is codified in a constitution or basic administrative framework that is difficult for the central government to modify unilaterally and that creates checks and balances among central and subnational entities. In unitary systems, decentralized government units are created by the national government and operate on the basis of delegated powers that can be changed unilaterally by the center.
4. It is beyond the scope of this paper to explore the extensive debates on the wisdom or feasibility of a decentralized or federated Iraq. Selected sources addressing these issues include Allawi (2007), Visser and Stansfield (2008), Visser (2010), McGarry and O'Leary (2007), and Natali (2010).

5. USAID's legislative strengthening handbook provides a useful overview of the elements of programming to build legislative capacity; see USAID (2000).

6. Iraqi Constitution of 2005, Article 117: "First: This Constitution, upon coming into force, shall recognize the region of Kurdistan, along with its existing authorities, as a federal region."

7. Iraqi Constitution of 2005, Article 121: "First: The regional powers shall have the right to exercise executive, legislative, and judicial powers in accordance with this Constitution, except for those authorities stipulated in the exclusive authorities of the federal government."

8. Although the primacy of the constitution and national law might be presumed in any legal system, this expression of a hierarchy among the laws in Iraq was a source of discussion and debate. In Article 13, First, the constitution declares itself to be: "the preeminent and supreme law in Iraq" and in Article 13, Second: "[n]o law that contradicts this Constitution shall be enacted." While this article may have established the primacy of the constitution in the Iraqi hierarchy of laws, it did not (in the eyes of some provincial actors) establish a priority between national and provincial law. Article 114 lists a number of shared powers (customs, electricity generation and distribution, environmental policy, development planning, public health, education, and water) between the central and provincial authorities. Provincial officials interpreted this article as giving them significant authority to manage their affairs, and along with Article 115, which states that in cases of disputes over these shared powers, priority lies with regions and governorates, as even justifying the disregard of central government rules.

Article 122 states that provinces shall be granted significant decentralized administrative and financial authorities (see Box 1, on page 4). Provincial officials saw this article as further justification for advocating for subnational autonomy and for considering the councils to be, in essence, provincial governments. However, councils are not the only governmental entities with territorial jurisdiction. Provincial councils, at the time that LGP was operating, bore no responsibility for public service provision, which instead fell to departments of central government ministries. The Law of Governorates, in Article 7, Sixth, signals provincial councils not to tread on the jurisdiction of the ministries by monitoring their departments, which the law excludes from such provincial oversight as "offices under federal jurisdiction."

9. In most taxonomies of decentralization, as Note 3 describes, deconcentration is the most limited form, consisting of geographically dispersed units of central government entities, where the center retains primary decision-making authority (see Brinkerhoff \& Johnson, 2009). 
10. CPA Order 71, Preamble.

11. CPA Order 71, Section 2, Paragraph 3.

12. At the end of June 2004, the CPA returned sovereignty to the Iraqi Interim Government, which served as a caretaker until the Iraqi Transitional Government could be installed following elections to the Iraqi National Assembly in January 2005. Once seated, parliament, after months of delays, eventually approved a Transitional Government in May. The primary responsibility of the Transitional Government was to draft a new constitution to replace the TAL, convene national elections under that constitution, and cede authority to a successor government (see Feldman and Martinez, 2006).

Article 61 of the TAL required that a constitution be completed by August 2005 and be submitted for approval in a nationwide referendum by October, but in August the Constitutional Committee charged with completing the draft had to be dissolved due to irreconcilable conflicts among its members. It was replaced by the Leadership Council, which brokered a compromise, essentially delaying discussion of those contentious issues, thus preventing agreement until after elections. The compromise secured parliamentary approval of a draft and ratification of the document on schedule, which paved the way for parliamentary elections in December.

13. Because Iraq's system of government was (and remains) fundamentally a ministerial one, there was scarcely any aspect of life that was not the subject of a central government ministry and covered by a ministerial regulation. Such regulations severely restricted the provincial councils and governors from exercising autonomous authority.

Recognizing this conflict between the competencies given to them by Law 21 and the apparently contradictory authority maintained by the central ministries, the Dhi Qar provincial council submitted the issue to the Shura Council, the highest ranking judicial authority for the resolution of constitutional disputes. However, the Council refused to hear their claim on the grounds that (essentially) the provincial council lacked standing to sue.

The Shura Council is a deliberative body within the Ministry of Justice, created by Law 65 of 1979, to resolve disputes of a constitutional nature between governmental entities. Although provincial and sub-provincial councils existed at the time of the law's passage (such councils having been created by a law dating from 1969), they were not explicitly mentioned as within the Shura Council's jurisdiction in the 1979 law. Instead, the Shura Council was intended to resolve disputes between governmental entities in which a ministry was a party. The law creating the Shura Council did not give it jurisdiction over the provincial councils at that time, and although the character of those councils changed since ratification of the 2005 Constitution and Law 21, the law determining the jurisdiction of the Shura Council had not. In addition to lacking standing, the Dhi Qar provincial council also lacked a dispute. They were asking the Shura Council for an advisory opinion, not a ruling.

According to the jurisdiction statute of the Federal Supreme Court, Law No. 30 of 2005, the Supreme Court is empowered to resolve conflicts "between the federal government, regional governments, provincial governments, municipalities, and local administrations." Raising doubt as to whether the provincial council is equivalent to the "provincial government" described in the Supreme Court's statute of jurisdiction, between August 16 and September 1, 2010, the Court refused to hear cases submitted to them by various provincial councils, encouraging the litigants to look to the Shura Council instead. For more on the Supreme Court, see Visser (2011).

14. Within the legislative branch, the upper house of the national legislature called for by Article 65 of the Constitution had yet to be formed, and the standing Committee on Regions and Governorates within the lower house had constituency offices in the provinces, but held no power to resolve provincial disputes. Within the executive branch, the Minister of State for Provincial Affairs was not a Minister of Local Government, having few staff and no rulemaking or adjudicatory powers. In addition, the High Commission for Coordination among the Provinces called for by Article 45 of the Law of Governorates and consisting of provincial governors met only rarely and at the pleasure of the prime minister.

15. On January 26, 2010, the Shura Council issued model bylaws for adoption by provincial councils. By that time, however, all provincial councils had bylaws of their own, as required by the Law of Governorates, Article 7, Third and Fourteenth, and only Maysan and Salah ad Din provincial councils took any notice (LGP III 2010, p. 9).

Although cautioning the provincial councils that they were "subject to the Council of Representatives' monitoring," the Shura Council stated in Chapter VI, Article 34, of its model bylaws that standing committees shall "develop local legislation, decisions, and administrative orders" in apparent contradiction to its opinion of September 2009, which stated that provincial councils lacked the authority to legislate because the word "legislation" was omitted from the notice requirement of council "opinions" and "decisions" in Article 12 of the Law of Governorates.

16. As noted in LGP III (2010), "Using objective criteria, advisors helped PC members to reduce or combine committees to a more manageable number. For instance, after review, Diyala PC decided to reduce its committees from 19 to 13. Among the criteria that advisors studied was the frequency of meetings.... In Anbar, advisors suggested combining committees with common themes. Members of both the reconstruction committee and the engineering committee agreed that their groups could be effectively merged" (p. 4).

17. As noted in LGP III (2011), "LGP III assisted the provincial councils in establishing voting methods-steering the councils toward more modern ways of voting and recording votes other than by a mere show of hands. Advisors also provided guidance on documenting meetings, indexing legislation, and the retention of documents. Indeed, the provincial councils adopted most of the capacity-building recommendations made to them by LGP III advisors concerning new rules of procedure, monthly legislative schedules, recording of votes, documentation of meetings, documentation of resolutions, official gazettes, and administrative orders" (p. 14).

18. LGP III advisors adopted the use of the research report and the seven question method to assist in the development of provincial legislation from Seidman et al. (2003). This manual is available in Arabic at http://www.undp-pogar.org. In addition, LGP relied on Mahmoud Sabra's Manual on Legislative Drafting for the Iraqi Council of Representatives, also available (in Arabic) on the UNDP-POGAR website. 


\section{CPA Order 71, Preamble.}

20. This is one example of the shortcomings of the CPA's nation-building effort that various observers have commented on: reform templates that largely ignored the particular prior conditions of Iraq's governance system. See, for example, Allawi (2007), Diamond (2005), and Dodge (2003, 2012).

21. As noted in LGP II (2008b), “The regional Intergovernmental Fiscal Relations Conference was held in Najaf February 19-20. The Najaf Provincial Council hosted the conference in cooperation with LGP. Participants included representatives from eight South and South Central regional provinces. Approximately 110 people attended, including the Najaf governor, provincial council and provincial officials, two COR members, representatives of the MOF and the MOP, members of the provincial council Finance and Planning and Finance subcommittees, representatives of directorates general and the Treasury Department, university professors, and print and broadcast media representatives. The conference's primary goal was to create a mechanism for intergovernmental fiscal relations-a main pillar of decentralization in Iraq. A secondary goal was to lobby the COR to legislate Article 106 of the Iraq Constitution to ensure transparency of the central government's transfer of funds to provincial councils" (p. 26).

22. See Martins (2005) for details on the Commanders' Emergency Response Program. The majority of these funds supported short-term gap-filling and did not contribute to sustainable nation building.

23. Rapid Response Grants were awarded in the first and second years of LGP I for a variety of projects, including the refurbishment of schools and medical clinics, trash removal, repairs to sewage systems, water treatment, and electrical sub stations, among many others. "By March 30, 2005, 224 RRGswith a total value of $\$ 15.7$ million for Year 1 and $\$ 1.6$ million for Year 2 of LGP-were received and approved by USAID. Of this total, 213 were approved in Year 1 and the remainder in Year 2. Of the total number of approved grants, 196 were successfully completed, 6 remained incomplete, and 22 were canceled due to an inability to implement as a result of repeated insurgent attacks" (LGP, 2005, p. xi).

24. In 2006, LGP was charged by USAID with carrying out refurbishment projects to improve the offices of each of Iraq's 18 provincial governments. The purpose of the effort was to assist local government through renovations and the installation of new equipment that would increase the productivity of local governments and allow greater citizen access. LGP received refurbishment project applications from 17 provinces (all but Diyala). Refurbishment fund projects fell into three categories: information technology equipment, very small aperture terminal equipment, and office furniture/equipment and construction.

25. Provincial Reconstruction Teams were small civilianmilitary units that provided assistance to provincial and local government in improving governance and delivery of basic public services. See Perito (2007).
26. Since the restoration of sovereignty in 2004, each prime minister denied provinces the authority to collect taxes. In addition, in July 2010, the Council of Ministers' legal committee determined that Basrah provincial council was not within its rights in attempting to impose a surcharge on the issuance of passports and national identity cards because the constitution, in Article 28, First, states that no such tax shall be imposed "except by law." The denial of taxation by successive prime ministers and the Council of Ministers notwithstanding, shortly after the Law of Governorates had been adopted but before it had been implemented, the Federal Supreme Court issued an advisory opinion, No. 16, recognizing the authority of provincial councils to raise local revenues. It is perhaps significant that the question was presented to the court by Najaf province, which as mentioned previously instituted a pilgrims' tax on religious tourists without central government challenge. See Visser (2011) for a discussion of the role of the Federal Supreme Court in addressing issues of federalism and decentralization.

27. The language of the law that required a strategic plan for the province was general. In most provinces, however, "provincial development strategy" came to mean a process and a document. The Ministry of Planning supported the use of the PDS methodology developed with the assistance of LGP II, and the Ministry of Finance, in its 2007 budget circular, required the completion of PDS documents by all governorates.

28. The Provincial Development Strategy contained predefined elements that made the document comparable across provinces. These included the following:

Strength, Weakness, Opportunities, and Threats (SWOT): The SWOT analysis provides a general description of the province and evaluation of the critical properties relevant to developing a strategic plan.

Vision: The vision statement describes, in general terms, the future state of the province the PC aspires to achieve.

Visions of Sectors: The vision statements for individual sectors describe a desired future state of service delivery for the particular service(s).

General Objectives: The general objectives are sector objectives that are more precise than vision statements and are usually measurable so that there is a clear criterion and indicators can be established to define achievement.

Strategies: The methods or means the province prescribes to develop services are the strategies. They contain specific activities and quantitative development indicators for implementation monitoring.

Services Criteria and Indicators: The criteria for service delivery were developed in close cooperation with the ministries and defined the service level the provinces sought to provide. The indicators were measurements of service delivery that could provide a snapshot of conditions in the province. This information quantified progress in service delivery and allowed planners and policymakers to identify gaps between current conditions and the target service level. This gap analysis was extremely useful in developing strategies and prioritizing projects.

29. USAID supported National Development Strategy conferences through its National Capacity Development Program, called "Tatweer" ("development" in Arabic), which operated from 2006 to 2011 . However, there was little coordination between Tatweer and LGP. 
30. SIGIR (2013, pp. 103-104) notes the severity of Iraq's corruption problems.

31. The Quality of Life (QOL) 1 survey (October/November 2003) covered all 18 governorates, with a sample size of 7,500. The QOL 2 survey was administered in March/April 2004, the QOL 3 in September 2004, and the QOL 4 in January 2005. As noted in LGP (2005), "In the view of most survey respondents, access to electricity, employment, housing, and social welfare services have deteriorated since the end of the war. Subsequent QOL surveys have reported improvements in the quality and quantity of basic services. However, respondents expressed a general dissatisfaction with the protracted restoration of basic services" (p. 12).

32. According to QED Group (2010), “The GoI's [Government of Iraq's] failure to deliver essential services to its citizenry is a problem that could have a serious consequences and negative impact on all future development and reconstruction programs in Iraq regardless of the donor source. The need to return to seeking to improve basic services delivery is undeniable. Essential services-potable water, electricity, sanitation, and fuel-still are not available to most Iraqis after over 7 years of development activities in Iraq by multiple donors" (p. 53).

33. "In addition, provinces continued to link the survey results to provincial plans, and projects focusing on the improvement of services were included in the drafting of the 2012 PPLs" (LGP III, 2011, p. 26).

34. A significant accomplishment of the policy reform team in LGP I was convincing the Minister of Municipalities and Public Works to sign a decree authorizing a pilot project to devolve ministry responsibilities to select provinces. LGP worked with the minister in February 2004 to host a national Fiscal and Administrative Decentralization Conference. This event, and subsequent regional ones, helped persuade the minister to entertain a pilot decentralization program.

The minister sent a letter to the Council of Ministers requesting approval to delegate more responsibilities to the local councils at pilot locations. In reply, the Council of Ministers disapproved any delegation of authority. One of its objections was the devolution of service delivery authority to local councils that were not subordinate to the Ministry of Municipalities and Public Works (MMPW). The ministers also disagreed on how much authority should devolve to local managers under the pilot program. In response to these objections, the MMPW Steering Committee rewrote the Ministerial Order and resent it for approval. LGP advised the Steering Committee to involve the local councils in a service performance monitoring capacity. The LGP team also suggested that the local MMPW departments submit monthly reports to the local councils and that these reports provide an open and objective review of progress on the objectives and impact of the pilot program. LGP's advice and suggestions were adopted and included in a 2005 Ministerial Order. LGP continued to work with the technical task force to set guidelines for minimum service standards and related policies, but due to ongoing resistance in the Council of Ministers, the effort stalled once a new government was formed and a new minister appointed.

The issue came up again in the last session of the outgoing parliament before the start of national elections in early 2010. On January 25, the Presidency Council approved Law 20 of 2010, which sought to devolve the MMPW and transfer its staff, property, budget, and responsibilities to provincial governors. The hastily drafted law obligated provincial councils to write local ordinances reorganizing the ministry's staff under the governor. On May 25, Kerbala province succeeded in completing a new provincial structure for its Department of Public Works. However, on June 14, the Supreme Court enjoined further implementation of Law 20 and on July 15 declared it to be unconstitutional because it had not originated in the Council of Ministers.

35. Much has been written on this topic. Specific to Iraq, see Amato (2009) and Benomar (2004). For assessments of Iraq's constitution, see Brown (2005), Feldman and Martinez (2006), and McGarry and O'Leary (2007).

36. See Haddad (2011) for an interesting analysis of the drivers and dynamics of sectarianism in Iraq, and the differences between national political discourses and those of popular culture. 


\section{References}

Allawi, A. A. (2007). The occupation of Iraq: Winning the war, losing the peace. New Haven, CT: Yale University Press.

Amato, A. (2009). Constitution making under occupation: The politics of imposed revolution in Iraq. New York, NY: Columbia University Press.

Belman Inbal, A., \& Lerner, H. (2007). Constitutional design, identity, and legitimacy in post-conflict reconstruction. In D. W. Brinkerhoff (Ed.), Governance in post-conflict societies: Rebuilding fragile states (pp. 45-64). London, England: Routledge.

Benomar, J. (2004). Constitution making after conflict: Lessons for Iraq. Journal of Democracy 15(2), 81-95. doi:10.1353/jod.2004.0021

Booth, D. (2011). Introduction: Working with the grain? The Africa Power and Politics Programme. IDS Bulletin 42(2), 1-11. doi:10.1111/j.1759-5436. 2011.00206.x

Bouillon, M. E. (2012). Iraq's state-building enterprise: State fragility, state failure and a new social contract. International Journal of Contemporary Iraqi Studies 6(3), 281-299. doi:10.1386/ijcis.6.3.281_1

Brinkerhoff, D. W. (2008). Building local governance in Iraq: Limits and lessons. In L. Picard, R. Groelsema, \& T. Buss (Eds.), Foreign aid policy: Issues and debates for the next half century (pp. 109-129). Armonk, NY: M.E. Sharpe.

Brinkerhoff, D. W. (2011). State fragility and governance: Conflict mitigation and subnational perspectives. Development Policy Review 29(2), 131-153. doi:10.1111/j.1467-7679.2011.00529.x

Brinkerhoff, D. W., \& Johnson, R. W. (2009). Decentralized local governance in fragile states: Learning from Iraq. International Review of Administrative Sciences 75(4), 585-607. doi:10.1177/0020852309349424
Brinkerhoff, D. W., \& Tadesse, S. (2005, May). Creating representative councils in Baghdad (Lessons Learned Brief No. 6). Research Triangle Park, NC: RTI International. Available from the United States Agency for International Development (USAID) Development Experience Clearinghouse (DEC) website: http://pdf.usaid.gov/pdf_docs/ PNADD573.pdf

Brinkerhoff, D. W., Wetterberg, A., \& Dunn, S. (2012). Service delivery and legitimacy in fragile and conflict-affected states: Evidence from water services in Iraq. Public Management Review 14(2), 273-293. doi:10.1080/14719037.2012.657958

Brown, N. J. (2005). Constitutionalism, authoritarianism and imperialism in Iraq. Drake Law Review 53(4), 923-941. Available from http://students.law.drake.edu/ lawReview/?pageID=lrVol53-4

Diamond, L. (2005). Squandered victory: The American occupation and the bungled effort to bring democracy to Iraq. New York, NY: Times Books, Henry Holt and Company.

Dodge, T. (2003). Inventing Iraq: The failure of nation building and a history denied. New York, NY: Columbia University Press.

Dodge, T. (2012). Iraq: From war to a new authoritarianism. London, England: Routledge.

Feldman, N. (2004). What we owe Iraq: War and the ethics of nation building. Princeton, NJ: Princeton University Press.

Feldman, N., \& Martinez, R. (2006). Constitutional politics and text in the new Iraq: An experiment in Islamic democracy. Fordham Law Review 75(2), 883-920. Available from http://ir.lawnet.fordham. edu/flr/vol $75 /$ iss $2 / 20 /$

Haddad, F. (2011). Sectarianism in Iraq: Antagonistic visions of unity. London, England: C. Hurst and Company.

Ismael, J. S., \& Ismael, T. Y. (2010). The sectarian state in Iraq and the new political class. International Journal of Contemporary Iraqi Studies 4(3), 339-356. doi:10.1386/ijcis.4.3.339_1 
Johnson, R. W., \& Silva-Morales, R. (2011). Budgeting under resource abundance and hesitant steps to decentralized investment planning and budgeting in Iraq. In C. E. Menifield (Ed.), Comparative public budgeting: A global perspective (pp. 203-221). Sudbury, MA: Jones and Bartlett Learning.

Lake, D. A. (2013). Iraq: US approaches to statebuilding in the twenty-first century. In D. Chandler \& T. D. Sisk (Eds.), The Routledge handbook of international statebuilding (pp. 293-304). London, England: Routledge.

Local Governance Program (LGP). (2005, June). Local Governance Program: final report. Available from the USAID DEC website at http://pdf.usaid.gov/ pdf_docs/PDACF553.pdf

LGP II. (2007a, October). Republic of Iraq district government field manual. Volume I (Version 2). Available from the USAID DEC website at http:// pdf.usaid.gov/pdf_docs/PNADL282.pdf

LGP II. (2007b, September). Republic of Iraq district government field manual. Volume II: Resources (Version 1). Available from the USAID DEC website at http://pdf.usaid.gov/pdf_docs/PNADL281.pdf

LGP II. (2007c, November). Writing the future: Provincial development strategies in Iraq. Volume 1 (Version 1). Available from the USAID DEC website at http://pdf.usaid.gov/pdf_docs/PNADN070.pdf

LGP II. (2008a, October). Government of Iraq federal budget process: Investment budget (Report written for USAID Iraq LGP II, contract no. 267-C-00-0500505-00).

LGP II. (2008b). Quarterly activity report for JanuaryMarch 2008 (Report written for USAID Iraq LGP II, contract no. 267-C-00-05-00505-00).

LGP II. (2009). LGP II final report (Report written for USAID Iraq LGP II, contract no. 267-C-00-0500505-00).

LGP III. (2009a). Formulating budgets for Iraq's provinces: A step-by-step guide for governors' offices and provincial councils (Report written for USAID Iraq Local Governance Program - Phase III [LGP III], contract no. DFD-1-00-05-00129-00).

LGP III. (2009b). Monthly report, June 2009 (Report written for USAID Iraq LGP III, contract no. DFD1-00-05-00129-00).
LGP III. (2010). Iraq Local Governance Program - Phase III, quarterly report, January-March 2010. Available from the USAID DEC website at http://pdf.usaid.gov/pdf_docs/PDACR181.pdf

LGP III. (2011). Local Governance Program - phase III: Final report (Report written for USAID Iraq LGP III, contract no. DFD-1-00-05-00129-00).

Martins, M. (2005). The Commander's Emergency Response Program. Joint Forces Quarterly 37, 46-52. Available from http://www.ndu.edu/press/ lib/pdf/jfq-37/JFQ-37.pdf

McGarry, J., \& O’Leary, B. (2007). Iraq's Constitution of 2005: Liberal consociation as political prescription. International Journal of Constitutional Law 5(4), 670-698. doi:10.1093/icon/mom026

Natali, D. (2010, October). Can federalism work in Iraq? (Event report). Washington, DC: National Defense University, Institute for National Strategic Studies. Available from http://www.ndu.edu/inss/ docuploaded/Can\%20Federalism\%20Work\%20 in\%20Iraq.pdf

National Research Council, Committee on Evaluation of USAID Democracy Assistance Programs. (2008). Improving democracy assistance: Building knowledge through evaluations and research. Washington, DC: The National Academies Press.

Organisation for Economic Co-operation and Development/Development Assistance Committee (OECD/DAC). (2008). Concepts and dilemmas of state building in fragile situations: From fragility to resilience. Available from http://www.oecd.org/dac/ incaf/41100930.pdf

Paris, R., \& Sisk, T. D. (2009). Conclusion: Confronting the contradictions. In R. Paris \& T. D. Sisk (Eds.), The dilemmas of statebuilding: Confronting the contradictions of postwar peace operations (pp. 304-316). London, England: Routledge.

Perito, R. M. (2007, March). Provincial reconstruction teams in Iraq (Special Report 185). Washington, DC: United States Institute of Peace. 
QED Group, LLC. (2010, August). Local Governance Program Phase III (LGP III) midterm evaluation and assessment of future opportunities: Final report. Available from the USAID DEC website at http:// pdf.usaid.gov/pdf_docs/PDACR554.pdf

Samuels, K. (2009). Postwar constitution building: Opportunities and challenges. In R. Paris \& T. D. Sisk (Eds.), The dilemmas of statebuilding: Confronting the contradictions of postwar peace operations (pp. 173-196). London, England: Routledge.

Seidman, A., Seidman, R., \& Abeysekere, N. (2003). Assessing legislation: A manual for legislators. New York, NY: United Nations Development Program, Regional Bureau for Arab States, Program on Governance in the Arab Region. Available from http://www.legislativeconsulting.com/resources/ manuals/Seidman_AssessingLegislation.htm

Special Inspector General for Iraq Reconstruction (SIGIR). (2009). Hard lessons learned: The Iraq reconstruction experience. Washington, DC: SIGIR. Available from www.sigir.mil

SIGIR. (2013). Learning from Iraq: Final report of the Special Inspector General for Iraq Reconstruction. Washington, DC: SIGIR. Available from www.sigir.mil

U.S. Institute of Peace and U.S. Army Peacekeeping and Stability Operations Institute. (2009). Guiding Principles for Stabilization and Reconstruction. Washington, DC: U.S. Institute of Peace Press.
United Nations. (2010). Reconstructing public administration after conflict: Challenges, practices and lessons learned. World Public Sector Report 2010 (Publication No. ST/ESA/PAD/SER.E/135). New York, NY: United Nations, Department of Economic and Social Affairs. Available from http:// unpan1.un.org/intradoc/groups/public/documents/ un/unpan037819.pdf

USAID. (2000, February). USAID handbook on legislative strengthening (Technical Publication Series, document no. PN-ACF-632). Washington, DC: USAID; Bureau for Global Programs, Field Support, and Research; Center for Democracy and Governance. Available from http://www.usaid.gov/ sites/default/files/documents/2496/200sbb.pdf

Visser, R. (2010). A responsible end? The United States and the Iraqi transition, 2005-2010. Charlottesville, VA: Just World Books.

Visser, R. (2011). Policing a messy federation: The role of the Iraqi Federal Supreme Court, 2005-2010. Orient 52(2), 12-18.

Visser, R., \& Stansfield, G. (Eds.). (2008). An Iraq of its regions: Cornerstones of a federal democracy? New York, NY: Columbia University Press.

Whaites, A. (2008). States in development: Understanding state-building (DFID Working Paper). London, England: Department for International Development, Governance and Social Development Group, Policy and Research Division. Available from http://tna.europarchive. org/20081212094836/http:/dfid.gov.uk/pubs/files/ State-in-Development-Wkg-Paper.pdf 


\section{Acknowledgments}

The authors gratefully acknowledge financial support for this research from RTI's International Development Group Executive Vice President and from the Fellows Program. We also thank the two external reviewers for helpful comments and suggestions. 
RTI International is an independent, nonprofit research organization dedicated to improving the human condition by turning knowledge into practice. RTI offers innovative research and technical solutions to governments and businesses worldwide in the areas of health and pharmaceuticals, education and training, surveys and statistics, advanced technology, international development, economic and social policy, energy and the environment, and laboratory and chemistry services.

The RTI Press complements traditional publication outlets by providing another way for RTI researchers to disseminate the knowledge they generate. This PDF document is offered as a public service of RTI International. 